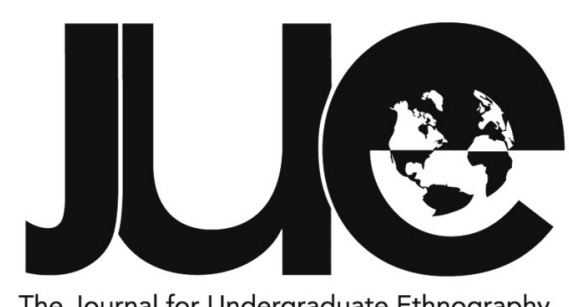

The Journal for Undergraduate Ethnography

\title{
"We are similar, but different": Contextualizing the Religious Identities of Indian and Pakistani Immigrant Groups
}

\section{Ravi Sadhu}

\section{Claremont McKenna College, rsadhu19@cmc.edu}

\section{ABSTRACT}

This article explores how Indian and Pakistani immigrant groups from the Bay Area in North California relate to and interact with one another. There is limited research on the role of religion in shaping sentiments of distinctiveness or "groupness" among diasporic Indians and Pakistanis in the UK and North America. Through conducting qualitative interviews with 18 Indian and Pakistani immigrants in the Bay Area, I recognized three factors pertaining to religion that were salient in influencing notions of groupness-notions of modernity, sociopolitical factors, and rituals. With respect to these three variables, I flesh out the spectrum of associated groupness; while some factors were linked with high levels of groupness, others enabled the immigrant groups to find commonality with one another. This research is integral to a better understanding of the interactions between South Asians in the diaspora, as well as to gain insight into how these immigrant groups-whose countries of origin share a history of religious conflict-perceive and interact with one another.

Keywords: Indian-Pakistani immigrant interactions; religious othering; Hindu-Muslim relations 
W e share the same food, same language, same sense of humor, same sensibilities; religion is the only difference," Junaid explained to me nonchalantly. As part of my endeavor to understand the interactions of Indian and Pakistani immigrants in the Bay Area, I spoke with Junaid-a Pakistani immigrant whom I found through Facebook-about one of his friendships with an Indian friend. After our conversation, a light bulb flashed in my head; I realized that I heard different iterations of the same claim from both Indians and Pakistanis"We are similar, but different."

As Junaid's comment suggests, one theme that $\mid$ found to be salient in expressing difference between the two immigrant groups was religion. The history of the Indian Subcontinent suggests why this was an expected outcome. Heightened political tensions and disagreements between the Indian National Congress and the Muslim League from 1945-1947 led to the formation of India and Pakistan as independent nation states in 1947 (Pandey 2001, 21). What was perhaps unexpected was the rampant violence during the chaotic migration of millions of Hindus and Sikhs towards India and Muslims towards Pakistan, resulting in "the drawing of borders based on headcount of religious identity-so many Hindus versus so many Muslims-would force people to flee what they considered 'safer' places where they would be surrounded by their own kind" (Butalia 1998, 3). In this manner, the Partition amplified notions of distinctiveness between Hindus and Muslims on the basis of nationality. Ethno-religious and political conflicts between India and Pakistanthe independence of Bangladesh in 1971, the Kargil War of 1999, and the never-ending dispute over Kashmir (Khan 2017, 209)-have arguably resulted in further divergence of the countries on the basis of ideologies rooted in religion. In the words of historian Yasmin Khan (2017), “In a close approximation of each other,
India and Pakistan swiftly moved to consolidate their nations and to define themselves as autonomous states using all the national apparel they could muster.... None of this is too surprising, but the 'other' state necessarily became an object of comparison, a counterpoint, and was, to a greater or lesser extent, vilified in the process" (208). While Khan's comment is a reflection of India and Pakistan as distinct and opposing nation states, a subject of consideration is whether ordinary Indians and Pakistanis also view each other from such a perspective. It therefore becomes imperative to better understand how factors such as religion have shaped conceptions of distinctiveness, particularly biased and pejorative ones, among Indians and Pakistanis.

In order to better understand how Indian and Pakistani communities identify with each other, diasporic environments such as the Bay Area are worth investigating. This is especially important considering that for diasporic South Asians "religious affiliations have played an increasingly important role in community formation, and they have shaped the ways in which South Asians have identified and mobilized themselves in the United States as well as engaged with the political process in their home countries" (Mishra 2016, 7). Indians and Pakistanis from the two newly formed South Asian countries started gradually moving to the Bay Area from the 1950s onwards (Rajan and Sharma 2006, 6), resulting in stable Pakistani and Indian communities in close proximity today. This proximity enables us to analyze how Indian and Pakistani immigrants relate to one another on the basis of religion. Thus, this study explores how religion (Hinduism and Islam) influences notions of exclusion and inclusion among Indian and Pakistani immigrants in the Bay Area. Three factors related to religion will be analyzed: notions of modernity, sociopolitical factors, and rituals. For each factor, sentiments of distinctiveness and/or commonality among the two groups will be contextualized with respect to Rogers Brubaker's (2002) theory of "groupness" and the phenomenon of religious othering. 
Theoretical Framework:

\section{Understanding Groupness and Religious Othering}

Due to the demographics of the participants I interviewed, most Pakistani immigrants addressed being Muslim, and similarly, most Indian immigrants spoke of being Hindu. This difference in religious identity became an avenue through which some immigrants expressed feelings that they belonged to two separate groups. While trying to provide nuance to this Indian/Pakistani and Hindu/ Muslim binary, a pertinent question to consider is, how do we account for the multitude of diverse religious traditions, sociopolitical values, and lifestyles that fall under the two categories of "Hindu" and "Muslim"? The work of Rogers Brubaker (2002), a sociologist interested in questions pertaining to ethnicity and nationalism, can help address this question. He states: 'Group' functions as a seemingly unproblematic, taken-for-granted concept, apparently in no need of particular scrutiny or explication. As a result, we tend to take for granted not only the concept 'group', but also 'groups'-the putative things-in-the-world to which the concept refers" (163). In an attempt to distance ourselves from groups, Brubaker writes about the importance of shifting our focus to "groupness" (169). By distinguishing consistently between categories and groups, we can problematize-rather than presume-the relation between them. We can ask about the degree of groupness associated with a particular category in a particular setting, as well as the political, social, cultural, and psychological processes through which categories get invested with groupness (Petersen 1987). We can ask how people-and organizations-do things with categories.

Using Brubaker's (2002) terminology, we can think of Pakistani and Indian immigrants as belonging to two different groups with religion being one category that determines their groupness. Brubaker astutely points to the fact that "Hindu" and "Muslim" identities are taken for granted when they are written about in academia and even colloquially. He suggests that we must invest in the scholarly pursuit to better understand groupness: "the sense of belonging to a distinctive, bounded, solidary group" (Brubaker 2002, 20). In the context of this study, we must shift our attention from Pakistani and Indian immigrant groups themselves to the fluid, dynamic processes of how these immigrant groups redefine, remold, and self-identify in relation to these groups. Understanding that groupness is fluid helps to explain why certain categorical differences that immigrants use to identify themselves can lead to conflict or distinctiveness; however, other forms of identification may lead to situations of neutrality or even commonality. For instance, Indians and Pakistanis in South Asia may have feelings of animosity towards one another while Indian and Pakistani immigrants in the Bay Area feel connected due to a shared culture and similar immigrant struggles; differences in religious and political ideologies, beliefs, and practices may fade into the background for some and resurface occasionally. Thus, we need to focus on how Indian and Pakistani immigrants themselves address and characterize the categories of "Hindu" and "Muslim," and how associated notions of groupness explain patterns of belonging, the dynamic process of identity building, and selfunderstanding in the context of the two religious categories.

In order to understand groupness among the two immigrant groups, I argue that we need to consider religious othering; that is, when a group is viewed or treated as inferior in comparison to one's own group. The scholar Diana Dimitrova (2017) provides an excellent analysis of othering in a universal context.

While the players may change: depending on who the speaker is, it may be the West, the East, colonial nations or formerly colonized nations, Hindus, Muslims, heterosexuals or the gay/lesbian community, men or women, who are, or imagine themselves to be, in the position of power and who are "othering" the other party (without necessarily "orientalizing him/her/it/them"). (8)

She suggests that any group can perceive another group as the "other" on the grounds of nationality, religion, gender, et cetera through asserting power or dominance over that group. Thus, experiencing a sense of distinctiveness or groupness (using Brubaker's terminology) is not 
enough for othering to occur; additionally, the other group must be perceived as inferior, marginal, or a threat. In the contemporary South Asian context, religious othering certainly plays a role in shaping groupness among Indians and Pakistanis. Religious persecution of minorities including Hindus has been an issue in Pakistan, and Hindu communities and religious sites have been attacked during political or ideological conflict with India (Isaphani 2017, 64). In a strikingly parallel manner, Indian Muslims are perceived as the other by the majority Hindu community and are often considered to be sympathizers or supporters of Pakistan on account of their religion (Ahmed 1998, 47). Furthermore, riots across Indian cities since 1947 resulted in attacks on Muslim ghettoes, which are stereotyped as "Mini Pakistans" (Tripathi 2016, 20).

Apart from internal national issues, foreign diplomacy, or military conflict, there are more implicit ways religious "othering" manifests in South Asia. We can see these notions implicated in some Indian films, which generically depict Pakistani men as terrorists and Pakistani women as oppressed on account of their religion (Daiya 2008, 153). We can also see religious othering in Pakistani social science textbooks; the Indian and subtly implied "Hindu" other is considered to be the enemy of Pakistan, seeking to destroy it through military and other means (Naseem and Ghosh 2010, 38). Limited research has been done on notions of religious othering among Indian and Pakistani immigrants and whether or not we observe similar notions in the diaspora. What is noteworthy is that these notions of religious othering in the Bay Area are influenced not only by the perceptions of religious communities in immigrants' countries of origin that they have grown up with, but also by the perceptions of the host country's inhabitants who may perceive people belonging to South Asian groups as the racial, religious, or even cultural other.

This leads to a key consideration: How do Indian and Pakistani immigrants relate to one another on the basis of religion, particularly based on the categories of "Hindu" and "Muslim"? To find plausible answers to this question, I utilized Brubaker's (2002) theory of groupness and notions of religious othering to design the methodology of a study involving 18 participants from the Bay Area in Northern California.

\section{Methodology}

This study was funded through the History Department of Claremont McKenna College. All of the interviews were conducted in the Bay Area during the summer of 2018 (June-August). In that time period, I conducted 18 interviews with Indian and Pakistani immigrants. The interview questionnaire was based on a list of scholarly articles and books, and it addressed various themes such as how participants formed opinions of their neighboring country growing up and how these opinions were affected when they interacted with immigrants from the other group in the USA. Furthermore, the questionnaire explored their take on contested political events between the two countries and immigrant journeys and experiences. I recruited participants through a host of ways: my personal network of family friends, friends they referred me to, national associations, and social media groups. The latter set of groups included the Alliance of South Asians Taking Action (ASATA), the Pakistani Association of San Francisco (PASF), the Pakistani American Community Center (PACC), and the Facebook Community of Post Colonial Memes for Oriental Minded Teens.

The cohort primarily consisted of working professionals with white collar jobs and college students. I have changed all participant names to guarantee anonymity. Table 1 provides details about the characteristics of each respondent. I ensured that the age range of the overall group was vast (20-96 years of age), and that both females and males were represented. The cohort was extremely diverse and included individuals who grew up in distinct parts of Pakistan and India. It was uncommon for immigrants to permanently stay in the United States upon immigration. After their studies or gaining work experience, many returned to Pakistan or India, lived there for a couple of years, and decided to move to/back to the Bay Area at some point. Since I am unable to provide so much detail in one table, I have indicated how long it has been since they last moved to the Bay Area. Interviewees had 
Table 1: Participant Characteristics

\begin{tabular}{|c|c|c|c|c|c|c|}
\hline Participant & $\begin{array}{l}\text { Immigrant } \\
\text { Group }\end{array}$ & Gender & Age & Profession & $\begin{array}{l}\text { Where they } \\
\text { grew up }\end{array}$ & $\begin{array}{l}\text { Years in the } \\
\text { Bay Area }\end{array}$ \\
\hline Sravya & Indian & $F$ & 20 & Student & Hyderabad & 3 \\
\hline Fiza & Indian & $\mathrm{F}$ & 31 & Tech & Hyderabad & 3.5 \\
\hline Durga & Indian & $\mathrm{F}$ & 32 & Doctor & $\begin{array}{l}\text { North, East } \\
\text { and South } \\
\text { (cities and } \\
\text { towns) }\end{array}$ & $\sim 5-7$ \\
\hline Madhavi & Indian & $\mathrm{F}$ & 49 & Tech & Bangalore & 23 \\
\hline Gopal & Indian & $M$ & 53 & Tech & Hyderabad & 27 \\
\hline Anvesh & Indian & $\mathrm{M}$ & 54 & Tech & Delhi & 26 \\
\hline Arun & Indian & M & 60 & Tech & Kolkata & 26 \\
\hline Mohan & Indian & $M$ & 62 & Education & Varanasi & 39 \\
\hline Arjun & Indian & $M$ & 96 & Retired & $\begin{array}{l}\text { Karachi } \\
\text { (before Parti- } \\
\text { tion) and later } \\
\text { Mumbai }\end{array}$ & 14 \\
\hline Sayyed & Pakistani & $M$ & 21 & Student & Lahore & 3 \\
\hline Ali & Pakistani & M & 24 & Consultant & Karachi & 1 \\
\hline Junaid & Pakistani & $M$ & 28 & $\mathrm{n} / \mathrm{a}$ & Islamabad & 17 \\
\hline Mehnoor & Pakistani & $\mathrm{F}$ & 31 & Business & Islamabad & 5 \\
\hline Ayesha & Pakistani & $\mathrm{F}$ & 33 & Tech & Karachi & 3.5 \\
\hline Amina & Pakistani & $\mathrm{F}$ & 33 & Diplomacy & $\begin{array}{l}\text { town close to } \\
\text { Islamabad }\end{array}$ & 4 \\
\hline Zaid & Pakistani & $M$ & 36 & Tech & $\begin{array}{l}\text { Gujranwala } \\
\text { and Lahore }\end{array}$ & 4 \\
\hline Fatima & Pakistani & $\mathrm{F}$ & 41 & $\mathrm{n} / \mathrm{a}$ & $\begin{array}{l}\text { Many places, } \\
\text { especially } \\
\text { Karachi }\end{array}$ & 2 \\
\hline Imtiaz & Pakistani & M & 50 & Sports & Karachi & $\sim 25$ \\
\hline
\end{tabular}

immigrated to the Bay Area during different decades-while some moved here 30 years ago, the younger interviewees arrived three years ago or so. This enabled me to capture potential interactions between and experiences of Indian and Pakistani immigrants across decades and during diverse time periods.

There were some limitations to this study. First, the distribution of gender and age could have been more equitable among both groups. 
Both immigrant groups consisted of five men and four women, meaning that more men than women were included in the study (ten versus eight). Furthermore, since all women who participated were between 20-49 years of age, all interviewees over 50 were men. Overall, the Pakistani immigrants interviewed were younger in comparison to the Indian immigrants; this might have impacted the number of years that Pakistani immigrants spent in the Bay Area, which was generally fewer than the Indian immigrants.

There was also a lack of diverse representation of religious and socioeconomic backgrounds-mostly higher income and highly educated Indian Hindu and Pakistani Muslim immigrants were interviewed. Additionally, most of these interviews were done over the phone. While it is believed that telephone interviews result in the loss of non-verbal data, research suggests that it can enable interviewees to reveal sensitive information (Novick 2008, 398). Additionally, telephone interviews might be most appropriate when the anonymity of participants is required (Block and Erskine 2012, 432). Supporting these claims, I found that telephone interviews were ideal for discussing sensitive topics such as participants' own familial struggles during the Partition, religious violence, and stressors faced in the USA as immigrants. The fact that they were able to speak to me from the comfort of their homes in a private manner guaranteed that the interview was a safe and secure space for them, which I believe enabled some to feel more comfortable opening up.

\section{Delineating Groupness through Modernity, Sociopolitical Factors, and Rituals}

Using Brubaker's (2002) theory of groupness to guide the analysis of the interview material, I found three main factors that oriented the groupness of the Indian and Pakistani immigrant groups: notions of modernity, sociopolitical factors, and rituals. Each of these factors link to a variety of themes, such as identity politics, racism, food, festivals, and sites of prayer. For each of the three factors, I will point to the complex ways groupness is highlighted by the immigrants who I spoke with-some factors led to commonality while others led to high levels of distinct groupness. I will especially highlight instances of religious othering that were apparent for each category. Religious othering reveals extreme and contentious reasons for why and how strained relations exist between Indian and Pakistani immigrants, and are therefore important to examine.

\section{Modernity}

Timothy Mitchell (2000) suggests that modernity is associated with a "staging of progress, or the advancement of civilization" (20). At the root of modernity lies a comparison-one group's history and progress is inherently superior to another excluded group, which structures the perceived inferior group as the other. For instance, Mitchell (2000) highlights the "West" and the "non-West" comparison (5). The West was considered as the agent of technological advancement and development, while the non-West was static, unchanging, and inferior in its outlook, values, and social progress. In the case of the immigrants I spoke with, modernity of the two countries was determined by the perceived nature and predisposition of the majority religious group in each country. In other words, interviewees were invested in the debate of whether Islam or Hinduism was more progressive and religiously tolerant. Several Indian immigrants perceived Islam as regressive and the reason behind army rule and religious intolerance in Pakistan. On the other hand, few Pakistani immigrants expressed that Indians are Islamophobic, intolerant, or even superstitious on account of their Hindu beliefs. In this section, I will explore how participants expressed groupness between Indians and Pakistanis on the basis of perceived "modern" values.

\section{Pakistanis are "Islamic"}

Seven Indian immigrants revealed to me that they grew up with the notion that "Pakistanis are Muslim." The term "Muslim" did not seem to be just descriptive; rather, it was used pejoratively to categorize Pakistanis as regressive and parochial on account of being Muslims. By analyzing interviewees' use of the term Muslim to describe Pakistanis, I found that groupness manifested in two ways. First, in 
reference to national narratives, groupness was based on a comparison of "secular Indians" and "religious Pakistanis." Several Indian immigrants implicitly suggested that Pakistanis were unable to adapt to modern principles of religious tolerance and governance due to the fact that they were Muslims. A more extreme iteration of this groupness was apparent in Mohan's (62, Indian) justification for why Pakistan was "unstable, militaristic, and financially poor". He explained: "The belief of Hindu religion and Islamic religion is inherently different...Islamic leaders incite Muslims in the mosque....Hinduism is almost the opposite. There is a sect of Hinduism that is more militaristic, but that is the minority. But even today in the world, in all Muslims countries, religion and state are most closely aligned." Mohan's comment suggests a clear distinction between Hinduism and Islam with national undertones. He perhaps implied that India is an inherently peaceful and functional nation because Hindus form the majority of the country, and their religion espouses peace and tolerance towards other religious communities. Pakistan, on the other hand, is "Islamic" and therefore violence, instability, and an affinity for regressive beliefs comes naturally to its people (suggested by the image of "inciting Muslims in the mosque"). Mohan's claim is similar to neo-Orientalist tropes in Europe and the West that render Arabs and Muslims as the other who are incapable of modernizing or adopting democracy in comparison to patrons of democracy and peace, such as America (Schmidt 2014, 169).

Yet another way groupness manifested was through three Indian immigrants directly comparing themselves to Pakistani immigrants. Through evaluating lifestyle and career choices that appeared to be motivated by religion, these Indian immigrants viewed themselves as more suited to a Western life and better acclimated to contemporary American lifestyles. Madhavi's (49, Indian) comparison between her Pakistani colleagues' wives and her is particularly reflective of this type of groupness. She felt that Pakistani women were bound by strict religious norms instead of pursuing a career: "A woman is not considered equal in Pakistan...honor killings. I could also see among my coworkers. Now their wives are probably working. At that time, they always stayed at home and were burqa clad. At the time, they were driven by religion." The long pause followed by her emphasis on "honor killings" during the interview created the impression that Madhavi believed that Pakistani women are seen as inferior to men due to rigid religious norms in the country that attempt to subjugate women and inflict violence upon them if they do not comply. Interestingly, she highlighted honor killings as if it is not a phenomenon that occurs in the Indian or Hindu context. She also seems to suggest that Pakistani immigrants abide by the same rigid religious norms that people in Pakistan follow-suggested by the women's choices to wear a burqa and stay at home. What is particularly noteworthy is that she, a working unveiled Hindu woman from India, seems to be the point of comparison here. Prior research highlights how women are held as "embodiments of modernity and tradition," particularly through analyzing their clothing in South Asian communities across national lines (Khurshid and Shah 2019, 190). The way in which Madhavi scrutinized Pakistani women (particularly through clothing) as an indication of Pakistan's backwardness is deeply reminiscent of the manner in which discourse has presumptuously deemed Muslim women to be oppressed both in the West (Khurshid and Shah 2019, 193) and India on account of their veil. Not only was groupness asserted between the women in each immigrant group, but also Madhavi's view of Pakistani women as bound by strict religious rules highlights how she othered Pakistani women as well. In this manner, Indian immigrants compared themselves to their Pakistani counterparts in two distinct ways. They expressed how India was more modern in comparison to an "Islamic" Pakistan. Furthermore, they also highlighted how modern Indian immigrants themselves based their ideas on their liberal religious beliefs that made them superior and open-minded immigrants in comparison to Pakistani immigrants.

\section{Indians are "Intolerant"}

Pakistani immigrants also expressed their thoughts about Hinduism and Indians' religious tolerance in a less frequent and more abstract manner (only four immigrants addressed 
Indians as Hindus more generally). Interestingly, the same groupness based on national narratives that was evident among the accounts of Indian immigrants was also addressed by Pakistani immigrants, who suggested that Indians were religiously intolerant and regressive in their outlook (comparisons between immigrant groups were not discussed as much). Their premise is the antithesis of the "Indians (Hindus) are secular and progressive" argument that several Indian immigrants like Mohan expressed.

Sayyed (21, Pakistani), for instance, spoke about his perception of India growing up and how his grandfather's experiences during the Partition made him feel that "India" was religiously intolerant: "My grandfather used to tell me stories about how his college educated Indian affiliates before the Partition told him that 'either you have to convert to Hinduism or leave.' Growing up, I used to think that I'm lucky to be born in Pakistan as opposed to being born as a Muslim in India." Sayyed's emphasis on the fact that his grandfather's colleagues were educated is fascinating as it hints at the importance of education as a determinant of modernity and development among Indians and Pakistanis (Khurshid and Shah 2019, 191). He stresses that education did not have an effect on the views of the Hindus his grandfather worked with, implicating the perception of Hindus as jingoistic and unchanging in their discriminatory ways. As I see it, he also extrapolated the views of his grandfather's colleagues and imposed it on Hindus in contemporary India, implicitly characterizing Indians as religiously intolerant people who are anti-Islamic and a threat to Muslims. In Sayyed's comments, the generalization of Indians (particularly Hindus) across time and space certainly stands out.

Amina (33, Pakistani) also addressed the difference between Hinduism and Islam in different words: "Religion [Hinduism] is perceived as very narrow-minded and superstitious. And then we see a lot of things on TV about how they treat their minorities....In Indian dramas, we see superstitions. Those umm-what do you call those religious people-they do magic and all that? That's not common in Pakistan now." Amina draws a boundary between the two nations based on a perception that Hinduism is fundamentally rooted in superstition and magic, unlike religion [Islam] in Pakistan. Interestingly, she makes a direct link between the religiosity of Hindu TV characters in Indian serials and news showing violence against religious minorities in India, highlighting how Hinduism is closely related to violent acts committed by the state. Her comment paints Hindu practitioners as fanatic; they are blind believers in superstitions and also perpetrators of violence against religious minorities, which hints at the regressive nature of Hinduism. The perceptions that she speaks about other Hindus in a strikingly similar way to how Mohan othered Muslims.

\section{Sociopolitical Factors}

Politics and religion are closely intertwined. As political scientist Sangay Mishra's (2016) research has indicated, South Asian immigrants in the USA are involved in and engaged with the politics of both America and their "home" countries through representing their ethnic and religious positionalities (166). This observation is especially relevant with respect to two hotbutton sociopolitical issues identified by immigrants that both involve the political and religious othering of Muslims: Hindu nationalism and Trump's rhetoric of anti-Muslim bigotry in a post-9/11 America. Considering the multiplicity of different experiences, political beliefs, and identifications, Indian and Pakistani immigrants expressed a spectrum of levels of groupness through their responses to how members of the other immigrant group reacted to the two political issues.

\section{Hindu Nationalism}

Since the Bharatiya Janata Party (BJP) came into power in 2014, many South Asians have been closely scrutinizing the party's leader, Narendra Modi, and Hindu nationalism in India. Six Pakistani immigrants voiced their concern over what they perceived as religious othering against Muslims in various parts of India in the past few years. Various topics were discussed: the BJP and its perceived anti-Muslim rhetoric, mob lynching of Muslims, human rights concerns in Kashmir, as well as meat and its precarious association with Muslims in India. For some Pakistani immigrants, the increasing incidents of Hindu nationalism resulted in them experiencing higher levels of groupness with 
their Indian friends and acquaintances. However, other immigrants from both groups found that they shared similar views on religious extremism, particularly in India and more generally in South Asia.

Highlighting how support for the BJP resulted in groupness, Ayesha (33, Pakistani) addressed how she could easily relate to a specific Indian friend, but her friend's family's support for Modi during the 2014 elections made her reconsider this relatability: "I think, for me, what was particularly upsetting was seeing educated upper class Indians being willing to vote for a demagogue [Narendra Modi] who was virulently 'anti-Muslim' and 'anti-Pakistan' and like very nationalistic-it was deeply upsetting, and remains deeply upsetting for me." Her commentary about the BJP is telling. Ayesha highlights the intersection of class and relatability among Indian and Pakistani immigrants. She had earlier revealed that she felt that upper class elite Indians and Pakistanis (such as from "Bombay-Karachi or "LahoreDelhi") have a sense of commonality in the USA. According to Brubaker and Cooper (2000), commonality is the sharing of a common attribute that facilitates groupness (20). The commonality that Ayesha alluded to was due to similar upbringings, educational backgrounds, and subsequent analogous immigrant struggles and aspirations. Arguably, Ayesha also suggested that this commonality is due to a mutual investment in liberal and secular political values that are not in favor of religious orthodoxy or extremism (either Islamic or Hindu). The fact that her friend supported a leader whom she perceived as both Islamophobic and Pakistanphobic made her feel that her Indian friend's family were not very similar to her own in terms of their political preferences concerning secularism.

On the contrary, some Indian and Pakistani immigrants were in agreement with each other about contested issues of religious extremism in India, such as the increased incidence of mob lynching Muslims over suspicion of beef-eating since 2014 (Sathyamala 2019, 879). Durga (Indian, 32) revealed that she rarely addressed India-Pakistan politics with her Pakistani friend. However, the "WhatsApp situation of mob lynching" (BBC News 2015) was something she was comfortable talking about, and in fact, her friend voiced similar concerns about bombings in Karachi, Pakistan. So whenever they talk about politics, they talk about how "stupid people are." Various participants' perspectives such as Durga's made it evident that conversations surrounding political issues in both countries are typically not brought up lightly or frequently by either immigrant group. However, upon discussion of these issues, Indian and Pakistani immigrants may find that they have a similar stance on political issues with religious undertones happening in South Asia. Durga's experiences suggest that even though the Hindu nationalist movement may aim to be exclusive, it paradoxically serves as an avenue through which South Asians of different religious backgrounds in the Bay Area can find a sense of commonality to condemn it. Joint efforts at activism are already in progress in the Bay Area-through immigrant and South Asian American leftists fighting against religious extremism in South Asia (Maira 2016, 148), or through community building among South Asians centered around an inclusive platform of social justice, human rights, and gender (Narayan and Purkayasta 2009, 175). The anthropologist Aminah Mohammad-Arif (2007) also highlighted such joint efforts through "progressive organizations" in the USA that particularly seek "harmony and rapprochement between the different South Asian communities and for peace in the Subcontinent, in particular between India and Pakistan" (12).

\section{Politics in America}

Apart from politics in South Asia, understanding how Pakistani-Indian immigrant interactions were impacted by political events in the USA is integral for a deeper understanding of the different ways that South Asian immigrants identify and relate to American ideologies and political views. Upon inquiring about this, several incidences that participants spoke about included President Donald Trump's anti-Muslim campaign, the travel ban Trump implemented in 2017 to block residents from six predominantly Muslim countries from entering the USA (Rose-Redwood and RoseRedwood 2017, 1), and racialized hate crimes towards South Asians in a post-9/11 USA. Yet again, I noticed that participants expressed a range of sentiments of groupness that were 
based on support for Trump or lack thereof, and even as a response to racialized hate crimes. Generally speaking, however, immigrants from both countries cited racism, hate crimes in America, and protesting Trump during the past few years as avenues through which they could find solidarity with the other group.

Two participants highlighted how, implicitly or explicitly, Indians supported American antiMuslim rhetoric. Fatima (41, Pakistani) laughingly expressed a "difference between us and the Indians" based on the fact that Indian parents she knew supported Trump in 2016 and voted for him. She remarked: "I perceived a fundamental difference based on sociopolitical values." Though Fatima laughed about the situation, her "us versus them" distinction indicates the serious implications of political choices that stem from support for an anti-Muslim ideology. Events in America such as supporting leaders or parties that contribute to the othering of Muslims or responding indifferently during moments of religious bigotry can sometimes highlight and exacerbate differences between Indians and Pakistanis. Examples include the efforts of some Hindu immigrants and Hindu Americans to establish a dissociation with Muslims and a Muslim identity post-9/11 (Kurien 2007, 190); likewise, showing support for Republican leaders such as Donald Trump mirrors support for Modi by Indians (or perhaps supporting Trump and Modi), who are both perceived to be populist leaders promoting anti-Muslim rhetoric (Thobani 2019, 750).

On the contrary, Ali (24, Pakistani) mentioned that protesting the travel ban initiated by Donald Trump brought him closer to his Indian friends: "It was nice to see that Indians were aware that it was unjust and unfair that this adversely affects Muslims." Ali presents Indians (a Hindu majority group) as being distinct from Muslims in terms of the fact that they are not entirely impacted by anti-Muslim policies. Considering developments post-9/11, South Asian Muslims particularly have been bearing the brunt of racialized hate crimes and antidiscriminatory law and immigration policies (Mishra 2016, 89), while South Asian Hindus have been relatively less affected. Perhaps in this context, Ali highlights an "us versus them" analogy; however, this example of groupness does not have negative connotations like those found in Fatima's comparison of Pakistanis and Indians who voted for Trump. In fact, Ali appreciated the spirit of camaraderie from his Indian friends to empathetically raise their voice for those Muslim immigrants who were affected. In this manner, different ways Indian and Pakistani interviewees establish or oppose groupness with each other based on political or religious experiences can coexist, resulting in political and emotional support between the two groups.

Additionally, Sravya (20, Indian) addressed the same notion of solidarity in the face of religious ignorance in a different manner. She spoke of an incident where a 70-year-old Indian Gujarati man was beaten by a white man who called him a "brown terrorist." She reveals: "In that moment, it wasn't about India or Pakistan, it was more like: how could you do this to the brown community?" Similar to Ali's account, she also suggests that othering and religious-based stereotyping can bring Indian and Pakistani immigrants together. Brubaker and Cooper's (2000) ideas of self-understanding are pertinent to this conversation. We can comprehend self-understanding as "one's sense of who one is, of one's social location, and of how (given the first two) one is prepared to act" (19). Unlike Ali, Sravya's self-understanding highlights that during moments of hate crimes motivated by religious bigotry against brown looking people (irrespective of religion), various South Asian immigrants stand united as one "brown" community. This community transcends Indian-Pakistani or even Hindu-Muslim boundaries. Mohammad-Arif and Moliner (2007) make a similar observation: "The experience of migration has also fostered a common South Asian identity that transcends national, ethnic or religious cleavages. This panethnic, inclusive type of identification emerges at first as an exo-definition by the host society, whose representations, categorizations and policies tended to lump together people from the sub-continent" (14).

\section{Rituals and Religion}

Rituals play an essential role in both asserting belief and creating a sense of belonging among 
those who participate together in performing or practicing them. However, when rituals are employed to create a distinct community, the practice of these rituals can define who belongs and who is excluded. With respect to the participants, three rituals were prominent: food, sites of prayer, and celebrating festivals. This section will demonstrate that for religious-based food preferences, contrasting levels of groupness were observed. However, sites of prayer and celebrating festivals together enabled immigrants to challenge notions of separate groupness on the grounds of religious identities and nationality.

\section{Food}

For some participants, food was seen as a divisive force that separated Hindus from Muslims. Fatima's (40, Pakistani) account is suggestive: "I have a group of [Pakistani friends] who believe that you can't go and eat at an Indian person's house. An Indian friend of mine-she would never come to my house to eat. Even if she would come to my house, they would not eat or drink anything....These are things they probably grew up with, that you can't go to a Muslim's house and eat." Fatima's comment is fascinating because it shows the extent to which her Indian friend allowed herself to interact with a Pakistani Muslim-she would visit Fatima's house but never eat there. Rigid food norms many Hindu communities may follow are rooted in caste notions of purity (Pechilis and Raj 2013, 60). These norms may be more aggressively followed by Hindus in the Bay Area relative to India because immigration from India has historically been an upper class and upper caste phenomenon (Kurien 2007, 45). Fatima also suggests that Pakistani Muslims have their own notions of purity pertaining to food. A few religionists have highlighted how some Pakistani Muslims engage in caste-based prejudices that work to other Hindus and Christians (particularly lower caste people) on the basis of sharing food. This is done in ways that parallel how upper caste Hindus position lower caste Hindus and Muslims as the other in India (Fuchs and Fuchs 2020, 63). Based on Fatima's account, we gain one perspective on how food norms result in high levels of groupness and religious othering that can separate Indian Hindu and Pakistani Muslim groups in the Bay Area.
However, not all participants perceived food as a point of religious difference when interacting with people from the other immigrant group. For five immigrants, food was a point of similarity. They spoke of how sharing similar food cultures and eating with one another enabled them to become closer to their Pakistani or Indian friends. Junaid (28, Pakistani) spoke about connecting with an Indian friend through sharing food: "In college, I made a close friend named Vikram from Bombay. We are still in touch and hang out often. We share the same food, same language, same sense of humor, same sensibilities; religion is the only difference." His comment demonstrates that many Hindus and Muslims are not bound by orthodox food norms as Fatima's accounts suggested. This appears to be especially the case for younger Pakistanis and Indians. Junaid attributed food as a branch of the category of culture (along with language and humor) that is distinct from a religious "mode of categorical identification" (Brubaker and Cooper 2000, 15). For immigrants such as Junaid and Vikram, sharing food and eating with one another highlighted cultural commonality between the two countries rather than exacerbating religious differences.

\section{Prayer and Sites of Worship}

Unlike food, which served as a point of contention between Pakistani and Indian immigrants in some cases, encountering other immigrants at sites of worship enabled several to resolve qualms or contentions about the perceived religious "other." This operated on two levels: between Indian and Pakistani Muslims and between Indian Hindus and Pakistani Muslims.

The key enabler of Indian-Pakistani Muslim interactions was the mosque, which four Muslim interviewees spoke of. Fiza (31, Indian) talked about how her mosque enabled her to make Pakistani friends: "The mosque is an example of how you have many, many diverse cultures around the world. One of my closest Pakistani friends I met at the mosque...you get to meet and know diverse communities. I have met people from countries I've never even heard of." Fiza highlights that the collective experience of attending the mosque, praying together, and observing festivals enabled 
practitioners to resolve differences based on nationality, ethnicity, and race that extended beyond South Asian markers of differences in identity (such as the Indian Muslim-Pakistani Muslim marker). She found that many of the stereotypes she grew up with of Pakistanis being "uneducated and violent" were disproved based on her experiences at the mosque. Her revelation implies that Indian Muslims may harbor negative stereotypes of Pakistani Muslims based on media or popular perception, causing Indian Muslims to view them as the Muslim "other"-vice versa may hold true as well. The mosque therefore serves as a site where this type of religious othering and groupness can be challenged. Fiza's change in self-understanding is reflective of similar fraternal relations between Indian Muslims and Pakistani Muslims, who found many commonalities with one another based on culture and language, in New York in the 1970s (Khandelwal 2002, 70).

In terms of interreligious encounters between Indian Hindus and Pakistani Muslims, events in religious centers or prayers at home created avenues to better understand the religious other. Durga's experience with her Pakistani best friend Sanam is a testament to the fact that attending religious sites frequented by South Asians of all faiths can enable immigrants to become more openminded and reflective of religious misconceptions that they may harbor of the other religious group. In Durga's words: "Sanam and her husband are very religious, they read Namaz in front of me or in my bedroom. I have become quite comfortable with day to day Muslim life, instead of before where I often thought "what are these other people doing?"' Durga's experience highlights that an eye-opening visit to the mosque or temple is not necessarily required for immigrants to better understand the other group's religiosity. In Durga's case, she simply observed her friend doing her everyday prayers at her house, which made her comfortable with the everyday experience of being Muslim.

\section{Festivals}

Similar to encounters at sites of worship, the collective celebration of religious festivals had a unanimous positive impact on establishing commonality between both immigrant groups. For over 12 participants, both Hindu and Muslim festivals were opportunities to celebrate with South Asians of all faiths and nationalities. This was evidently the case due to two reasons: celebrating religious festivals in an inclusive manner growing up and the secular celebratory ethos of festivals in the Bay Area.

To varying degrees, both immigrant groups were considerably well-informed about how the other religious group (Hindus or Muslims) celebrates key festivals such as Holi, Diwali, and Eid due to their own prior experiences growing up or through media representations. Anvesh (54, Indian) and Gopal (53, Indian) both expressed their affinity for the celebration of Eid, eating food and being invited to iftar parties in their respective cities growing up. Fatima (41, Pakistani), a Muslim, spoke about her experiences with Hindu festivals in Karachi and how she would participate in Holifunctions hosted by some Hindu families who decided to stay back in Pakistan during the Partition. Several immigrants cited these as favorable opportunities to understand the other religious group in a more intimate fashion, suggesting that festivals were spaces where religious groupness could be challenged and remodified. Their accounts challenge conventional narratives that promote groupness, such as Pakistan celebrates Muslim festivals or India celebrates Hindu festivals, and highlight the hybrid inclusivity of South Asian festivals. From these accounts, one can sense that perhaps some Indians and Pakistanis carry an enthusiasm for celebrating religious festivals of diverse faiths with them from their countries of origin to the USA if they had prior experience or habit of doing so.

Additionally, South Asian religious festivals in the Bay Area can function as secularized social celebrations and parties that are slightly divorced from their religious origin and can include many people of many faiths. This enables Indians and Pakistanis to better understand different religious communities (Hindu, Muslim, Christian, et cetera) in an immersive and inclusive festive setting. Imtiaz (50, Pakistani) spoke of how religious festivals such as Diwali, Holi, Eid, and Ramzan were a means for his Indian friends and him to celebrate: “No matter what happens, we'll never 
say 'oh, we won't go to their [Indians'] house.' Like for Eid, we always invite our non-Muslim Indian Friends (i.e. Hindus and Christians). Whether it's dinners or parties, we will invite them. Doesn't matter if some war is happening, if the World Cup is happening." Imtiaz implies that his celebration of Eid is an inclusive social space for all South Asians irrespective of nationality and religion. While the associated religious rituals may be observed exclusively by Muslims, the accompanying celebrations involving food and entertainment can involve non-practitioners as well. His comment particularly stands out because he suggests that despite tensions between India and Pakistan (high levels of groupness), the inclusivity of Eid's festivities are not compromised.

\section{Conclusion}

At the root of Brubaker's (2002) exegesis of groupness lies the notion of distinctiveness between one's own group and another group. Essentially, groupness is a way to assert ideas of inclusion and exclusion between the self and the other. Indian and Pakistani immigrants may find a sense of commonality around certain factors, but they can also experience a sense of distinctiveness around other factors that sometimes leads to a more extreme form of groupness with impacts such as othering. In the context of the immigrants I interviewed, I found that there were a myriad of factors and agents that shaped how Indian and Pakistani immigrants understood how the two groups differed from a religious perspective. For many, family, educational institutions, and even the media were responsible for shaping immigrants' notions of historical and national narratives such as modernity. Notions of modernity that they grew up with often promoted high levels of groupness and even religious othering based on interpretations of how tolerant the majority religious community of the other country was. These notions of modernity are not mere abstract ideas; in fact, they tangibly affect Indian-Pakistani immigrant interactions. They can cause tension in relationships when Indian immigrants express skepticism or intense surprise about secular perspectives of Pakistani immigrants, or even when Pakistani immigrants suggest that Indians do not care about the status of Muslims in India.

Upon immigration, the ever-changing dynamics of internal policies, identity politics, and religious biases or othering in both the host country and the country of origin can cause the two immigrant groups to feel either estranged from or connected with one another. In the case of this specific cohort, the rise of Hindu nationalism in India and Trump's anti-Muslim rhetoric in post-9/11 America were pertinent sociopolitical factors. The support for Modi and Trump, speaking out on issues pertaining to religious hate-crimes such as mob lynching in India or racial profiling in the USA, and standing in solidarity with the other immigrant group played a major role in making some immigrants feel distanced from one another and shaping new modes of commonality for others. Furthermore, the way that these immigrants identified with each other also changed as a result of Americans' perspectives, which helps to explain why few immigrants actively spoke of themselves as "Muslims in America" while others identified with the idea of being "brown."

Apart from sociopolitical factors, rituals also played a key role in reifying notions of exclusion or separation between Hindus and Muslims and, by extrapolation, Indians and Pakistanis. Food norms stemming from beliefs of religious purity exacerbated notions of groupness or even religious othering when Indians and Pakistanis were unable to eat with one another. However, for several other younger immigrants, these food norms were not being adhered to, and in fact, sharing similar tastes in food and exchanging food with one another enforced ideas of cultural similarity and fraternity between the two immigrant groups. This highlights how religious notions of groupness are closely intertwined with gender, class, age, caste, and religious practice. Similar to how food exacerbated differences in some cases, entrenched groupness has repercussions of creating potential misconceptions between not only Indian Hindus and Pakistani Muslims, but also between Indian Muslims and Pakistani Muslims. However, rituals such as the opportunity to encounter the other religious group at their sites of prayer created a positive effect for a better understanding of the other 
immigrant group from an interreligious or intrareligious perspective. Similar to the positive effects of sites of prayer, celebrating festivals together-irrespective of religious or national boundaries-reinforced inclusivity, challenged typical notions of groupness, and provided an opportunity for immigrants to celebrate in solidarity.

All in all, a myriad of ideological, sociopolitical, cultural, and ritualistic modes of being intersected to shape how these Indian and Pakistani immigrants understand their religious identities in relation to one another, albeit differently for each immigrant and over time. As the acclaimed Nisid Hajari points out in his book Midnight's Furies: The Deadly Legacy of India's Partition, the rivalry between India and Pakistan "is getting more, rather than less, dangerous: the two countries' nuclear arsenals are growing, militant groups are becoming more capable, and rabid media outlets on both sides are shrinking the scope for moderate voices" (Hajari 2016, Epilogue). In order to allow for the rise of moderate voices that advocate for peace between the two countries, continued research must address the phenomena of groupness and religious othering among Indian and Pakistani communities while searching for ways to explain and challenge them in South Asia and beyond. 


\section{Acknowledgements}

Most importantly, I sincerely thank all of the participants in my study for giving me their time and sharing their honest opinions and stories about their lives. I am grateful to the History Department at CMC for its funding and mentorship. The Tipparams deserve special recognition for accepting me into their home and family for the summer of 2018. Lastly, and by no measure the least, l'd like to sincerely thank my Religious Studies professors at college and all of my teachers in Bangalore and Claremont who enabled and encouraged me to think critically about the world around me. 


\section{References}

Ahmed, Ishtiaq. 1998. State, Nation and Ethnicity in Contemporary South Asia. United Kingdom: Pinter.

BBC. 2018. "India Lynchings: WhatsApp Sets New Rules after Mob Killings." January 25, 2020. https://www.bbc.com/news/worldasia-india-44897714.

Block, Emily S., and Laura Erskine. 2012. "Interviewing by Telephone: Specific Considerations, Opportunities, and Challenges." International Journal of Qualitative Methods 11 (4): 428-45. https://doi.org/10.1177/160940691201100409.

Brubaker, Rogers. 2002. "Ethnicity without groups." European Journal of Sociology 43 (02): 163-89. https://doi.org/10.1017/ S0003975602001066.

Brubaker, Rogers, and Frederick Cooper. 2000. "Beyond Identity." Theory and Society 29 (1): 1-47. https://doi.org/10.1023/ A:1007068714468.

Butalia, Urvashi. 2003. The Other Side of Silence: Voices from the Partition of India. Durham, NC: Duke University Press.

Daiya, Kavita. 2008. Violent Belongings: Partition, Gender, and National Culture in Postcolonial India. Philadelphia: Temple University Press.

Dimitrova, Diana, ed. 2017. The Other in South Asian Religion, Literature and Film: Perspectives on Otherism and Otherness. London: Routledge.

Fuchs, Maria-Magdalena, and Simon Wolfgang Fuchs. 2020.

"Religious Minorities in Pakistan: Identities, Citizenship and Social Belonging." South Asia: Journal of South Asian Studies 43 (1): 5267. https://doi.org/10.1080/00856401.2020.1695075.

Hajari, Nisid. 2017. Midnight's Furies: The Deadly Legacy of India's Partition. Stroud, Gloucestershire: Amberley.

Ispahani, Farahnaz. 2017. Purifying the Land of the Pure: A History of Pakistan's Religious Minorities. New York: Oxford University Press.

Khan, Yasmin. 2017. The Great Partition: The Making of India and Pakistan. New Haven: Yale University Press. 
Khandelwal, Madhulika S. 2002. Becoming American, Being Indian: An Immigrant Community in New York City. Ithaca, New York: Cornell University Press.

Khurshid, Ayesha, and Payal Shah. 2019. “Claiming Modernity through Clothing: Gender and Education in Pakistani Muslim and Indian Hindu Communities." Gender and Education 31 (2): 189204. https://doi.org/10.1080/09540253.2017.1302077.

Kurien, Prema A. 2007. A Place at the Multicultural Table: The Development of an American Hinduism. New Brunswick, NJ: Rutgers University Press.

Maira, Sunaina Marr. 2016. The 9/11 Generation: Youth, Rights, and Solidarity in the War on Terror. New York: NYU Press.

Mishra, Sangay K. 2016. Desis Divided: The Political Lives of South Asian Americans. Minneapolis, MN: University of Minnesota Press.

Mitchell, Timothy. 2000. Questions of Modernity. Minneapolis, MN: University of Minnesota Press.

Mohammad-Arif, Aminah. 2007. “The Paradox of Religion: The (re) Construction of Hindu and Muslim Identities amongst South Asian Diasporas in the United States." South Asia Multidisciplinary Academic Journa/1. https://doi.org/10.4000/samaj.55.

Mohammad-Arif, Aminah, and Christine Moliner. 2007. "Introduction. Migration and Constructions of the Other: Inter-Communal Relationships amongst South Asian Diasporas." South Asia Multidisciplinary Academic Journal1. https://doi.org/10.4000/ samaj.136.

Narayan, Anjana, and Bandana Purkayastha. 2009. Living Our Religions: Hindu and Muslim South Asian American Women Narrate Their Experiences. Boulder, Colorado: Kumarian Press.

Naseem, Mohamed Ayaz, and Ratna Ghosh. 2010. "Construction of the 'Other' in History Textbooks in India and Pakistan." In Interculturalism, Society and Education, edited by Giovanni Pampanini, Faten Adly, and Diane Brook Napier, 37-44. Sense Publishers. https://doi.org/10.1163/9789460912498_004.

Novick, Gina. 2008. "Is There a Bias against Telephone Interviews in Qualitative Research?" Research in Nursing \& Health 31 (4): $391-$ 98. https://doi.org/10.1002/nur.20259. 
Pandey, Gyanendra. 2001. Remembering Partition: Violence, Nationalism, and History in India. Cambridge: Cambridge University Press.

Pechilis, Karen, and Selva J. Raj. 2013. South Asian Religions: Tradition and Today. London: Routledge.

Rajan, Gita, and Sharma Shailaja, eds. 2006. New Cosmopolitanisms: South Asians in the US. Stanford, California: Stanford University Press.

Rose-Redwood, CindyAnn, and Reuben Rose-Redwood. 2017. "Rethinking the Politics of the International Student Experience in the Age of Trump." Journal of International Students 7 (3): i-ix. https://doi.org/10.32674/jis.v7i3.201.

Sathyamala, C. 2019. "Meat-Eating in India: Whose Food, Whose Politics, and Whose Rights?" Policy Futures in Education 17 (7): 878-891. https://doi.org/10.1177/1478210318780553.

Schmidt, Silke. 2014. "The Framed Arab/Muslim: Mediated Orientalism." In (Re-)Framing the Arab/Muslim: Mediating Orientalism in Contemporary Arab American Life Writing, 137-90. Bielefeld: Transcript Verlag.

Thobani, Sitara. 2019. "Alt-Right with the Hindu-Right: Long-Distance Nationalism and the Perfection of Hindutva." Ethnic and Racial Studies 42 (5): 745-762. https:// doi.org/10.1080/01419870.2018.1468567.

Tripathi, R.C., and Purnima Singh, eds. 2016. Perspectives on violence and othering in India. New Delhi: Springer India. https:// doi.org/10.1007/978-81-322-2613-0. 